\title{
THE DECAY OF TIES
}

\author{
D.
}

American Wood.Dreserveri Á Asociation 


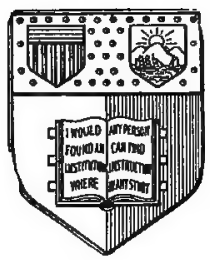

มี่ew Hark State Uallege at Agrirulture

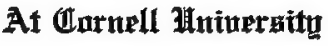
3thara, A. 1.

Ilithrary

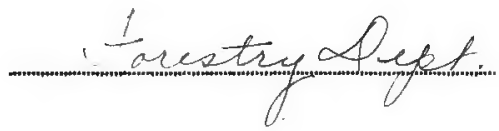

\section{DEPARTIENT OF FORESTRY}

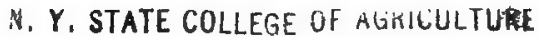
CORNELL UNIVERSITY, MHACA, N, $Y$. 
TF 254.H8

The decay of ties in storage,

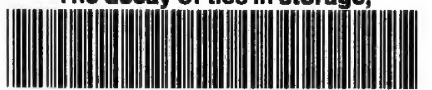

$\begin{array}{lllll}3 & 1924003 & 628 & 512\end{array}$ 


\section{Cornell University Library}

The original of this book is in the Cornell University Library.

There are no known copyright restrictions in the United States on the use of the text. 


\title{
The Decay of Ties in Storage
}

\author{
By C. J. HUMPHREY, Pathologist \\ Bureau of Plant Industry \\ Madison, Wisconsin
}

Prepared in co-operation with the

United States Forest Products Laboratory Madison, Wisconsin

Published by the

American Wood-Preservers' Association

Mt. Royal Station, Baltimore, Md. 
COPYRIGHTED, 1920

BX THE

AMERICAN WOOD-PRESERVIERS' ASSOCIATION 


\section{THE DECAY OF TIES IN STORAGE*}

By C. J. Humphrey

Pathologist, Bureau of Plant Industry, in Co-operation with the Forest Products Laboratory, Madison, Wisconsin.

The present paper was prepared at the request of your association for an article dealing in as simple terms as possible with the more common fungi which attack ties in storage. As the fungi concerned in the decay of such timbers vary to a considerable extent with the region and also the kinds of wood under consideration, a paper covering the situation in any comprehensive manner would necessarily be quite extensive, and would involve a careful study over the entire country. For this reason it was considered advisable by the writer to limit the discussion to those fungi commonly found on hardwood and pine ties throughout the centralt United States.

Several tie yards at Metropolis and Joppa, Ill., were selected as representative of this region. Ties are concentrated at these points in large numbers, coming in by rail or water from a wide tributary area. Upon arrival these ties are sorted and air seasoned and the obviously defective ones culled. These culls, running up into the hundreds of thousands, offered a very favorable field for study, as a large proportion had been culled for decay, much of which had developed before the ties reached the yards.

In the production of ties it is customary to yard them first locally near the point of cutting. Since many are rafted they are preferably yarded near the rivers, from which they can be reached at high water. Storage conditions at these local concentration points are usually very poor, and no particular care is taken to safeguard the stock from decay, hence many ties have to be rejected at these points by the buyers. Many others, however, find their way to the permanent yards, and when infected with fungi continue to deteriorate until fully air dried. It is only within comparatively recent years that the producers have even considered the use of many timber species known to be very susceptible to rot. At the present time, however, almost all species known to the local flora are acceptable if they otherwise conform to specifications. This has led to serious loss from decay, much of which is preventable.

In order to present the broader aspects of decay control I will digress at this point to indicate the fundamental factors involved in

\footnotetext{
*Acknowledgments. My thanks are due to Dr. C. L. Shear. Bureau of Plant Industry, Washington, D. C., for determination of the species of Hypoxylon, Daldinia, Hypocrea and Lasiosphaeria; to Dr. E. M. Gilbert, University of Wisconsin, for identification of Exidia glandulosa; and to Jennie M. Pitman, University of Wisconsin, for the coloring of the plates herein included. I wish also to express my appreciation to A. R. Joyce and others at Metropolis, Ill., for their many courtesies and assistance which made the study possible.

$\dagger$ Since the paper was originally prepared I have received request for another plate covering a few additional fungi most likely to be found on ties in the northern United States. Plate VIII has been included for this reason. Many of the fungi recorded for the more southern region, however, will likewise be found in the north.
} 
the development and spread of wood-destroying fungi, to which we attribute all the primary decays with which we are concerned.

\section{What Are Fungi?}

Fungi are plants, just as much as trees, shrubs and herbs. They merely differ in their form, lack of green coloring matter, and methods of nutrition. A tree gets its nutriment from the soil and air through its root system and leaves; the fungus derives its nutriment from the substrate upon which it grows, namely, wood or other vegetable matter.

In the life cycle of wood-inhabiting fungi we recognize two essential stages in development: (1) The mycelium (vegetative stage), which consists of fine, cotton-like branched threads which penetrate the wood and may also develop on the surface if the surrounding air be moist; (2) the fruiting stage, which produces spores at the surface of the timber. These spores may be found directly on the exposed mycelium, as in the case of "molds," but more often they are produced on definite fruit-bodies which are nothing more than mycelium compacted into characteristic shapes representative of different fungi.

Many fungi are wood inhabiting, but these may not all necessarily be wood destroying. For practical purposes it is, therefore, necessary to discriminate between two broad groups, namely, molds or stains and wood destroyers.

\section{Mycelium}

The mycelium is the stage which penetrates the wood. It is the absorbing system of the fungus and in function is comparable to the root system of ordinary green plants. In the case of "molds" and "blue stains," it mainly enters the ducts or pith rays of the wood where it feeds on the starches, sugars and other easily digested organic compounds. In the case of these fungi it may also pass through the pits in the walls of the wood fibers, but rarely bores through the solid wood substance. For this reason the molds and blue stain do not affect the strength of the timber to any appreciable degree.

The mycelium of both wood destroyers and molds is in many cases colorless and rather fine when growing within the wood; that of the blue stain is brown and usually coarse. The main difference between the mycelium of wood destroyers, molds and blue stain, however, is its action on the wood fiber, the wood destroyers having the capacity to attack and disintegrate the wood substance itself while the molds and blue stain act only on the starches, sugars and other organic substances stored in the pith rays and ducts.

The chemistry of wood is rather complex, but the main constituents of the wood substance itself are cellulose and ligno-cellulose (often termed lignin), and any fungi which have the ability to feed on these substances are necessarily wood destroying. These compounds, as well as others in the wood, are acted on by specific ferments (enzymes) 
which change them to simpler organic substances which can be absorbed by the fungus as food for its own growth.

\section{Fruiting Stage}

In order to propagate itself successfully every fungus must have a fruiting or spore-bearing stage. Spores are very minute bodies which in the case of molds are borne directly on the surface of superficial mycelium, and in the case of the blue stain fungi also in minute, black, flask-shaped fruit-bodies which appear as stiff bristles on the surface of the wood. The wood-destroying fungi, however, have conspicuous fruit-bodies whose shape, color and texture are quite characteristic for the different fungi. The spores are borne on or within these definite fruit-bodies.

Spores are entirely comparable in function to seeds. They are microscopic in size, extremely light, and appear in mass as a very fine powder, very often white, but the color may vary widely for the different fungi. Very often the spores from a single fruit body of the wood-destroying fungi will run up into the billions, most of them being capable under the right conditions of germinating to produce a new plant. With such an abundance of spores blowing about in the air and settling on new timber, it is seen that the chances for infection are very great, providing the conditions for their germination are favorable. The most important factor here concerned is moisture, both in the wood and in the atmosphere. The most active period for the casting of spores from the fruit bodies is during moist weather, which in turn is most favorable for germination and subsequent infection.

\section{Conditions Necessary for the Growth of Fungi}

The conditions necessary for the growth of fungi are: (1) The presence of an adequate food supply; (2) sufficient moisture; (3) at least a small amount of air; (4) a suitable temperature.

Food. This is furnished by the wood tissues and the more easily these tissues are attacked the more readily will the wood disintegrate. The sapwood of all the species of the region under consideration is non-resistant to fungus attack. The heartwood of the different woods, however, varies widely in this respect. The white oaks are highly resistant, as is also good red gum, while such species as beech, red oaks, medium grade yellow pine, hard maple and birch offer less resistance, and hackberry, elms, tupelo gum, cotton-woods, soft maple and low grade pines are easily rotted.

Moisture. A suitable amount of moisture is, without doubt, the most important factor in decay. The different fungi, however, appear to vary somewhat as to their water requirements. For infection and incipient decay a comparatively high moisture content of the wood and the surrounding air is highly favorable for all. After infection has once taken place, however, and the fungus has become established 
in the wood, the rate of decay may vary considerably with different organisms, depending on the amount of moisture present. For instance, there are many fungi which thrive only under humid forest conditions and will not develop on partially seasoned timber in storage, while others can tolerate a considerable amount of drying and still continue to decay the wood. It is safe to say that most of the fungi which rot structural timbers are quite resistant to drying when once established in the wood.

The term "dry rot" should not be used indiscriminately, as is rapidly becoming the case among laymen. While the writer thinks the designation should be retained, it should be limited in its scope so as to apply only to the decay produced by Merulius lachrymans and its close relatives, which are mainly of economic importance in connection with the decay of timbers in buildings. Even in this case the term is more or less of a misnomer, as these organisms always start under moist conditions. They have the capacity, however, of developing porous water-conducting strands which may spread from the moister portions of a building to dry timbers, whose decay is furthered by the moisture which the fungus carries.

Air. A certain amount of air in the wood is absolutely necessary for decay to take place. The fungi require it in their growth. When wood is saturated the air in the wood cells is displaced by water and fungus growth is impossible.

The opinion widely prevalent among laymen that alternate wetting and drying is necessary for decay has developed through observation of the way wood decays in exposed situations. For instance, take the case of an infected railway tie partly embedded in soil. During a very dry season there may not be sufficient moisture in the wood to permit decay, and the fungus will remain dormant. On the advent of rains, if only sufficient moisture falls to put the tie in good moisture condition, it begins to rot rapidly again and will continue to do so as long as the moisture and temperature are favorable. If, on the other hand, the rainy period is long continued, the tie may become saturated and decay will be retarded again until the stick dries out sufficiently to admit the necessary amount of air. Thus, in the alternation of wet and dry conditions, there occurs at some point intermediate between the dry and wet ranges a condition at which decay is at its maximum. If the moisture were held at this optimum point it can readily be seen that the stick would decay much more quickly than under the alternating conditions. Therefore it is only under fluctuating climatic conditions that alternation becomes of advantage.

Temperature. In general, the fungi under consideration grow best between 75 degrees and 90 degrees F. They will all grow at much lower temperatures, but much more slowly. The most severe winter conditions do not kill them. They merely cease growth and remain in 
a dormant condition. On the other hand, a rise of temperature of but a few degrees above the optimum has a greater influence on growth than a corresponding reduction. The practical purposes, however, we may say that nature so regulates temperature conditions that for the region under consideration the fungi find a very favorable environment over a considerable portion of the year.

\section{Control of Decay in Stored Ties}

With the foregoing considerations in mind relative to present commercial practices as coupled up with the fundamental conditions necessary for decay, it is seen that relief can only be secured by changing commercial practice as far as possible so as to eliminate infection and put the timber in a moisture condition unfavorable for subsequent decay.

Uintcr Cutting and Barking. The advantages in winter cutting lie in the fact that at this season both temperature and humidity are much less favorable for infection. It is true that air seasoning will be much slower at this season, but this can be increased by removal of the bark, which is also of advantage in controlling insect depredations. Slower seasoning is of particular value from a pathological standpoint, as it decreases the number and size of season checks which collect and retain moisture and thus offer favorable points for infection.

Proper Piling in Woods. At points of production ties should never be piled directly on the ground or allowed to lie about singly on the ground for more than a few days at most. Forest soil is full of living fungus, and being moist, infection is quickly carried over to timber in contact with it. In piling or yarding ties they should be placed on foundations well off the ground and amply ventilated beneath, the ties being spaced so as to allow as much ventilation as possible without undue checking. This preliminary seasoning in the woods is of very great importance, as apparently a large amount of subsequent decay is to be attributed to infection in the woods.

Transport of Ties. With partially seasoned ties rail transport would appear preferable to rafting from a pathological standpoint, but perhaps not from a practical, for every time a tie is wet it is put in a good condition for infection. The writer, however, does not wish to lay too much stress upon this point, as proper yarding and piling at destination will normally take care of the situation.

Yarding Ties at Destination. Inasmuch as ties may be stored for sometimes more than a year at terminal yards, careful attention must be given to piling them, particularly when they are rafted. Since many of the yards are on comparatively low ground, the first care must be given to drainage so that all rainfall or ground water may be immediately removed by seepage. A slag or cinder covering to a depth of 6 to 12 inches makes a very good surface which keeps the weeds down and allows rapid run off. 
The next attention should be given to foundations. The usual practice is to use two parallel rows of cull ties. In some yards ties of durable woods like white oak or chestnut are employed, but there is a tendency to use almost any sort of rejects or even pole timbers. Very often on soft ground these low foundations are pressed into the soil, so that the piles rest practically on the ground. The use of nondurable timbers with a large percentage of sapwood is, likewise, a highly objectionable feature. If it is necessary to use such material, the pieces should be given a pressure treatment with creosote or zinc. For permanent yards the use of concrete, preferably in the form of piers carrying treated or naturally durable stringers, would undoubtedly prove an economy in the long run. Such a foundation allows ventilation from the sides as well as the ends. The use of open, well ventilated, durable foundations cannot be emphasized too strongly, as infection may otherwise pass readily from the soil through the foundation timbers into the base of the piles.

The piling should also be as open as consistent with the checking of the timbers handled. With particularly perishable timbers the contact points should be reduced as much as possible.

In addition to the above, the yards should be kept absolutely free of vegetation and rotten or infected wood. Unless the yards are kept scrupulously clean of decayed wood, which can be of no possible use except for fuel, the other precautions taken will be in large part nullified. In handling the whole situation we must begin at the source and very obviously we must strike first at infections. The production of fruiting-bodies bearing the innumerable spores must be kept down. It is of no permanent value to remove and destroy these fruiting-bodies and leave the infected stick, for new crops will soon form again.

The fire hazard is also another feature to be seriously considered, for it is a well-known fact that rotten or punky wood will ignite very readily from a spark, follow into the sound stick and smolder for a considerable time ready to break out into flame when the wood becomes sufficiently dry and is fanned by a good breeze.

What Fungi Shall the Inspector Discriminate Against?

As previously indicated, this paper discusses mainly the more common fungi found on stored ties in the region investigated. Many of these, however, will be found over the entire country. In preparing this part of the article, many thousand cull ties of various kinds of wood, but largely the more perishable, were looked over at Metropolis, Ill., and representative samples bearing identifiable fruit-bodies were cut from the ends and shipped to the Forest Pathology Laboratory at Madison, Wis., for photographing and further investigation of the extent and seriousness of the associated rot. After photographing the end of the tie bearing the fungus, a 3 -inch disc, wherever possible, was cut off to show end penetration of the rot. The cut surface was 
smoothed with sandpaper and also photographed, and this section was then sawed through with the grain beneath the sporophores to show the longitudinal configuration of the infected or decayed area. About 125 photographs were thus made.

Very few fungi were found on white oaks, these being limited to four common species, mainly confined to the sapwood. At least nine species were found on red oaks, but here the difference in resistance between the heart and sapwood is not partictlarly marked, although the sap is often attacked first. Of the other hardwoods, red or sweet gum which was low grade heart or high in sapwood harbored at least four species of wood destroyers and was especially susceptible to stains. Beech was particularly attacked by the "button fungi" (Hypoxylon) and the "jelly fungus" (Exidia glandulosa). Pines were mainly infected with three fungi, only one of which, the brown fungus, Lenzites sepiaria, causes serious decay.

For the benefit of the inspector the fungi here reported may be thrown into three classes, of which only the first group need give serious concern.

\section{Group I-Fungi Which Attack Wood Severely Conifers (Pines, Hemlock, Tamarack, Etc.)}

Fomes roseus.

Lentinus lepideus.

Lenzites sepiaria.

Polystictus abietinus.

Daedalea confragosa.

Daldinia concentrica.

Exidia glandulosa.

Gloeoporus conchoides.

Hydnum erinaceum.

Hypoxylon cohaerens.

Hypoxylon coccineum.

Lenzites betulina.

\section{Hardwoods}

Lenzites trabea.

Panus stipticus.

Pholiota adiposa.

Polystictus pargamenus.

Polystictus versicolor.

Stereum fasciatum.

Stereum rameale.

Trametes sepium.

Group II-Fungt Which Attack Wood Slowly and Need Not Ordinarily be Discriminated Against

\section{Hardwoods}

Hypocrea citrina.

Schizophyllum commune.

Group III-Fungi Which Need Not Be Discriminated Against - Conifers

Blue-stain (Ceratostomella spp.). Schizophyllum commune. Peniophora gigantea.

\section{Hardwoods}

Blue-stain (Ceratostomella spp.).

Olive-black mold (Lasiosphaeria pezizula).

In order to identify these fungi the following key, based on the principal and more conspicuous characters, will be found useful. Following this the fungi are briefly described and information given as to their prevalence, distribution and species of timber attacked. 


\section{Key to the Fungi Described in the Present Paper}

A. Fruiting-bodies provided with gills on the lower surface.

1. Plants of the mushroom type with cap and central stem:

a. Frtiting-bodies fleshy-fibrous, yellow ish; upper surface sticky when moist and covered with brownish scales; on hardwoods. Pholiota adiposa.

b. Fruiting-bodies tough, fleshy-fibrous, white; upper surface of cap covered with brown scales. Lentinus lepideus.

2. Plants with only a short lateral stem:

a. Fruiting-bodies smail, tough, fiexible, grayish to tan colored; gills not split at edge; on hardwoods. Panus stipticus.

3. Plants without a stem:

a. Fruiting-bodies small, thin, white, tough and leathery when moist; gills split longitudinally at edge and halves rolled back; on hardwoods, pines and other conifers. Schizophyllum commure.

b. Fruiting-bodies medium large, shelving, corky, flexible when moist buff to clay colored or light brown; often concentrically zoned above; on hardwoods. Lenites betulina.

c. Fruiting-bodies corky, flexible, medium sized, and russet to dark brown in color; upper surface usually velvety to hairy; on conifers only. Lenzites sepiaria.

d. Fruiting-bodies as above but near to cinnamon brown; upper surface usually not velvety; on hardwoods. Lenzitcs trabea.

B. Fruiting-bodies with pores on the lower surface.

1. Plants shelving, densely clustered, thin, tough and flexible when moist; upper surface concentrically banded with shades of buff, brown or blue; under surface white; pores small and shallow; on hardwoods. Polystictus écricolor.

2. Plants as above but usually more loosely clustered; upper surface white, hairy; under surface violet in young specimens, becoming brown in older; pores break up into flattened teeth in age; on conifers. Polystictus abietinus.

3. Plants as above; upper surface velvety, whitish to creamy or buff in young specimens, becoming concentrically banded and gray behind in age, and losing velvety covering in part; under surface violet in young specimens, becoming brown. Plant splits radially and becomes lacerate at the margin as it matures and weathers; pores break up into flattened teeth in age; on hardwoods. Polystictus pargamenus.

4. Plants as above but usually smaller and frequently. running together where attached to surface of wood; under surface brownish-drab with pores visible to unaided eye; in fresh specimens pore layer stretches like rubber when fruiting-body is torn apart; on hardwoods. Gloeoporus conchoides.

5. Plants corky, flexible, medium sized, near to cinnamon brown; upper surface usually not velvety; under surface either with gills or radially elongate pores. Lenzites trabea.

6. Plants tough-fibrous to corky, usually joining at the sides to form long fruit bodies which are shelving, thick where attached to wood and project out usually less than half an inch; white when fresh, becoming pale buff in drying; pores large, easily seen by unaided eye; usually on oaks or chestnut. Tranetes sepium.

7. Plants large, shelving, tough, rigid when dry, 3 to 6 inches across and $1 / 2$ to $3 / 4$ inch thick, light brown; upper surface often rough to the touch; pores radially elongate or sinuous, easily visible to unaided eye; mainly on willow. Daedalea confragosa.

8. Plants shelving, tough, corky, becoming woody; pinkish to rosy throughout. Fomes roseus.

C. Fruiting-bodies provided with distinct teeth* which project downward.

1. Plant white, fleshy, succulent, more or less globose; usually on oak. Hydnum erinaceum.

D. Fruiting-bodies smooth (without gills, pores or teeth) beneath when shelving, or on outer exposed surface when spread out flat on the wood:

1. Plants shelving, arranged one above the other:

a. Fruiting-bodies thin, flexible; upper surface clay colored to slate colored; lower surface light brown; on hardwoods. Stereum fasciatum.

b. Fruiting-bodies as above but usually much smaller; lower surface orange-yellow; upper surface paler; on hardwoods. Stereum rancale.

* Polystictus pargaments and Polystictis abietinus also have flattened toothlike plates, due to the brealing up of the walls of the pores in age. 
2. Plants thin, spread out flat on surface of wood, not shelving:

a. Fruiting-bodies uatery-white to creamy or smoky gray, forming a somewhat cartilaginous membrane which dries to a brittle crust and is easily separable from the wood; mycelial stage very abundant as a fluffy-white growth of coarse matted threads; on conifers (pines, etc.) only. Peniophora gigantea.

b. Fruiting-bodies bright yellow, resembling paint; on hardwoods. Hypocrea citrina.

E. Fruiting-bodies in the form of smooth, or almost smooth, more or less globose "buttons."

1. Buttons small, numerous, black when mature, but covered with a clay colored "bloon" when young; on beech. Hyporylon colaerens.

2. Buttons somewhat larger, up to $1 / 4$ inch in diameter, reddish-brown; on beech. Hyporylon coccineum.

3. Buttons large, up to one or two inches in diameter, black tinged with olive green on the surface; charcoal-like and distinctly layered within; on hardwoods. Daldinia concentrica.

F. Fruiting-bodies black, crumpled, jelly-like. spread over surface of wood; wher: dry shrink to a thin, shiny, black, brittle membrane; on hardwoods. Eridiu glandulosa.

G. Fruiting-bodies minute, usually requiring magnifying glass to see; occur on surface of wood intermixed with mycelium.

1. Fruiting-bodies black, like stiff bristles with swollen base; mycelium matted, dark brownish to black; fungus produces blue discoloration in sapwood of both hardwoods and conifers, particularly red gum and

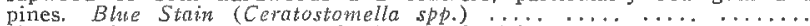

2. Fruiting-bodies minute, scattered, depressed globose seated on a compact olive brown to blackish felt-like mycelium growing over surface of wood; to casual observer looks like olive-black stain on the ends of ties; produces a bluish-black stain in the wood which does not extend far in. Olize black mold (Lasiosphaeria pezizula.)

\section{Brief Description of the Fungi Reported in the Present Paper}

In identifying the fungi found on structural timbers it should be kept in mind that the fruiting-bodies are very often small and abnormal or immature, making their determination correspondingly difficult. Each fungus, however, usually has sufficient well-marked characters so that even though the form and size be changed, other satisfactory clues remain to guide us. The present article cannot hope to cover the situation in more than a cursory fashion, but even the little offered may prove of some assistance, at least by stimulating an interest in the subject. Undoubtedly many more species than those recorded for the regions under consideration will turn up as the number of observers increase, and these will prove more or less confusing, as there is always a tendency in this kind of work to tie up the unknown with the known. In cases of doubt the services of an expert should be sought if the specimens, after careful comparison with the illustrations and descriptions herein given, fail to tally in the essential characters.

\section{Pholiota Adiposa}

(Plate VII, Figs. 2 and 6)

This is a moderately large, fleshy fungus of the mushroom type with an expanded cap and a more or less central stem. The cap is usually convex, sticky when fresh or moist, and covered with scattered brownish scales. The gills or plates on the underside of the cap are yellow at first but soon become brown, due to the abundance of rusty colored spores which are produced on their surfaces. The stem is rather thick, yellowish, and scaly over the lower portion. It is usually 
curved, as the cap must always orient itself so that it is horizontal, with the gills pointing downward.

The fungus grows in clusters and was noted several times on beech and red oak ties, growing from the heartwood, which was apparently rotted in the standing tree. It is not serious in storage yards since, as a rule, such heart-rotted ties are culled in the woods.

\section{LENTINUS LEPIDEUS}

(Plate VIII, Fig. 2)

This is one of the large mushrooms which mainly grows on timber in contact with the ground. It is tough, fleshy-fibrous, with a central scaly stem and is white throughout, except that the cap is covered with brownish scales. It occurs abundantly over the United States, appearing especially prevalent in regions with sandy soil, where it frequently grows out of ties or other structural timbers at or near the ground line. In the dark it produces sterile "stag-horn" growths.

It is limited to coniferous wood, where it rots both heart and sapwood of many species vigorously.

\section{Panus Stipticus \\ (Plate VII, Fig. 4)}

This is one of the smaller gill fungi. It usually grows in dense clusters and rarely projects out more than half an inch from the surface of the wood. It is of a grayish to tan color, somewhat scurfy on the upper surface, and is thin and flexible, with a short lateral stem. Like nearly all the leathery or corky species, it can revive repeatedly after periods of drying and form new crops of spores.

It is not very prevalent on stored ties, and was only found producing a sap-rot in red oak.

\section{Schizophyllum Commune}

(Plate VI, Figs. 5-10)

This is a very characteristic fungus with which there is no danger of confusing any other. It may grow on almost any kind of wood, and is abundant on conifers as well as hardwoods. It grows in the form of small shelves, usually not projecting out more than an inch. The fruit-bodies are often more or less wedge-shaped or fan-shaped, tapering to a narrow point of attachment. They are thin and flexible, like soft leather when moist, white or grayish tinged, densely clothed with short hairs above and provided with distinct radiating gills beneath, which may vary from a buff to pale slate gray in color. These gills are very characteristic, being split longitudinally along the edge, the halves curling back like a slit dandelion stem.

The spores of the fungus readily enter season checks and produce a crop of fruit-bodies in a very short time. In two samples of persimmon ties collected the fungus was associated with a marked bleaching of the dark wood and in certain areas a marked softening and disintegration of the substance, indicating that the fungus is apparently 
wood destroying but quite slow in its action. The above mentioned ties had been in storage several years. New pine ties bearing an abundance of the fruiting-bodies showed no perceptible effect on the fiber.

In the opinion of the writer the fungus need not be discriminated against, as the rot will not develop to any serious extent within normal periods of storage.

\section{LenZITES BetULINA}

\section{(Plate II, Fig. 3; Plate IV, Figs. 5 and 6)}

This is one of the corky, flexible, shelving species which project out one to three inches. The individual fruiting-bodies are borne one above the other, often in large, conspicuous clusters. The upper surface is velvety to the touch, usually clay colored to light brown, and often concentrically banded with yellow or orange shades. The young plants and growing margins are usually buff colored. The under surface consists of coarse gills radiating out to the margin. These are whitish to light buff in color.

This fungus occurs in all parts of the United States, and is likely to attack almost any hardwood. In the less durable woods, such as red oak, red gum, etc., it produces a marked uniform bleaching and rot of the heart as well as the sap. The fungus is a rapid grower and very destructive.

\section{Lenzites Seriaria}

(Plate I, Fig. 4 ; Plate V, Figs. 1 and 2)

Lenzites sepiaria is a shelving, tough, flexible fungus varying from russet to dark brown above and paler beneath. The upper surface is usually densely clothed with hairs, but in age these may be more or less weathered away. The underside consists of plates or gills radiating out from the point of attachment.

This fungus is widespread and common on coniferous timber over the entire United States. There are several closely related species in different parts of the country, but they are all brown and attack wood severely. One species (Lenzites trabea) rots hardwoods, but the others all grow on conifers.

\section{Lenzites Trabea \\ (Plate VIII, Fig. 5)}

This fungus is closely related to Lenzites sepiaria, but principally rots hardwood timber. It is moderately thin and shelving, and often loosely clustered. It differs from Lenzites sepiaria in being more of a cinnamon brown than sepia or dark brown, in the upper surface being usually devoid of a velvety covering, and in the underside being provided with gills which are closer together and which frequently join laterally (anastomose) to form elongate pores. 
Lenzites trabea is widely distributed over the United States, and is almost always found on hardwoods, of which it attacks a considerable number, among which oaks, gums, cottonwoods and willows deserve particular mention.

\section{Polystictus Versicolor}

(Plate I, Fig. 2; Plate IV, Figs. 7-9)

This is perhaps the most common fungus one meets with on hardwood timber. The fruit-bodies are thin, shelving and densely clustered one above the other. They are tough, leathery and flexible when moist, but more or less rigid when dry. The upper surface is beautifully banded concentrically with various shades of brown, blue or buff from which character the fungus takes it name, and is densely covered with short hairs, and hence velvety to the touch. The under surface is white with small, shallow pores scarcely visible to the unaided eye. This fungus attacks almost all species of hardwood timber and is very vigorous in its action, producing a white rot.

\section{Polystictus Abietinus$$
\text { (Plate VIII, Fig. 1) }
$$

This is a thin, flexible fungus usually growing in loose clusters. The fruit-bodies on structural timber rarely extend out more than an inch, usually less. They are white and hairy on the upper surface and usually violet on the lower when young, becoming brownish in age. The pores in this species break up at an early stage of growth into flattened, irregular teeth, but there almost always remain shallow pores at the margin.

The fungus is widely distributed over the entire United States, and is limited to conifers, where it produces principally a sap-rot.

\section{Polystictus Pargamenus (Plate VIII, Fig. 3)}

This fungus is found abundantly on hardwoods over practically the entire country. Its closest relative is Polystictus abietinus, which, however, grows only on conifers. The fruiting-bodies are shelving, clustered and thin. They are somewhat larger and coarser than Polystictus abietinus, but rarely project out on structural timber more than $1 / 2$ to 2 inches. In young specimens the upper surface is velvety and whitish to creamy or buff; in older specimens it frequently becomes concentrically banded and gray behind, losing much of its velvety covering. The under surface in young specimens is violet, which changes to brown in older specimens. The pores readily split into irregular flat teeth as the plant ages.

In hardwoods having a well differentiated heart it produces mainly a sap-rot, but in other species the heart may be decayed as well. 


\section{Gloeoporus Conchotdes \\ (Plate Vil, Fig. 5)}

The fruiting-bodies of this fungus are shelving, loosely arranged one above the other and usually run together where attached to the surface of the wood. On ties they rarely extend out more than $1 / 2$ to $3 / 4$ inch. The upper surface is light buff. The under surface is brownishdrab and provided with minute pores which require a hand lens to see. The species may easily be identified by the fact that the pore layer in fresh specimens, or in old specimens which have been moistened, stretches like a thin sheet of rubber when the fruiting-body is torn apart.

This fungus was noted several times, particularly on red oak, where it may rot both heart and sapwood. It has a wide distribution over the United States, principally on hardwoods.

\section{Trametes SePium \\ (Plate VII, Fig. 1)}

Fresh plants of this species are small, white, tough and firm, and project out from the wood less than half an inch. They are shelving and often elongated. As they dry they become pale buff and rather hard. The under surface bears large pores easily visible to the unaided eye.

The fungus is widely distributed on hardwoods, but mainly on white and red oaks and chestnut. It produces a brownish rot so severe that the wood readily crumbles between the fingers.

\section{Daedalea Confragosa \\ (Plate VII, Fig. 7)}

This fungus is a rigid shelving species which may be 5 to 6 inches across and projects out 2 to 3 inches. It is usually $\mathrm{I} / 2$ to $3 / 4$ inch thick where attached to the surface of the wood. The upper surface is brown, somewhat irregular, and rather rough to the touch. The lower surface is nearly the same color and provided with radially elongate, often sinuous, pores easily visible to the unaided eye.

The fungus is widely distributed over the United States, growing mainly on willow, and being largely limited to this species is rarely found in tie yards. It occurs most commonly on dead trees or on living trees which have been injured. It causes a uniform bleaching of the wood and a severe rot.

\section{Fomes Roseus}

\section{(Plate VIII, Fig. 4)}

This fungus is one of the larger fungi of the shelving type. The annual form is corky when fresh, but firm when dry. It is pinkish to rosy throughout, and for this reason easily distinguished. Old speci- 
mens may become black on the surface, but when broken open these usually show pinkish. The perennial forms may be hoof-shaped and consist of several annual layers of growth, but this type of fruit-bodies is much less common than the one illustrated. The pores are small but are visible to the unaided eye. This fungus is for the most part met with in the northern and western United States, where it rots coniferous ties of various species.

\section{HYDNUM ERINACEUM \\ (Plate VII, Fig. 3)}

This is a beautiful, white, fleshy fungus which has distinct teeth more or less cylindrical in section and tapering to an acute point. These teeth are long and conspicuous and bear the spores on their surfaces. The fungus is succulent and fleshy and more or less globose. It turns yellowish and shrinks markedly in drying. It was found a number of times on red oak and beech ties, always growing from the decayed heart at the ends. These ties were cut from trees already heart rotted in the forest, hence the rot is not of particular importance in the storage yards.

\section{Stereum Fasciatum}

(Plate III, Fig. 3; Plate IV, Fig. 4)

The fruiting-bodies of this species are thin, shelving, arranged one above the other, and may project out up to $1 \mathrm{I} / 2$ inches. The upper surface is clay colored and somewhat velvety in young specimens, becoming grayish to slate colored as the fungus matures. The under surface is light brown (avellaneous) and smooth, i. c., without pores, gills or teeth.

The fungus is widespread in the United States, but most abundant east of the Rockies. In the Gulf and South Atlantic States it is largely replaced by a similar appearing fungus, Stercum lobatum. It is partial to white and red oaks, but is known also to attack many other hardwoods. In the white oaks it mainly rots the sapwood, but with the red oaks and other of the less durable woods the heart is also decayed.

\section{Stereum Rameale}

\section{(Plate I, Fig. 1; Plate V, Figs. 3 and 4)}

This is one of the thin, tough, flexible species which produces a large number of small, shelving, confluent fruit-bodies, smooth on the under surface, and arranged one above the other in clusters. These fruit-bodies rarely project out from the surface more than half an inch, usually less on stored ties. They are a beautiful yellowishorange on the under surface, especially when wet, and somewhat paler on the upper surface, which is distinctly hairy. The fungus attacks many different hardwoods, such as red gum, red oak, etc., and is very common throughout the United States. 
Peniophora Gigantea

\author{
(Plate I, Fig. 3; Plate IV, Figs. 1-3)
}

This fungus is usually most evident as a fluffy whitish mycelium on the surface of the wood. On the ends of ties it forms radiating streaks or ridges which consist of the mycelium intermixed with exuding resin. The fungus is very often associated with blue stain. When fruiting-bodies are formed they consist of smooth, flat, waxy to subcartilaginous patches which are watery-white to creamy or smoky gray in appearance. The margin is whitish and usually more or less fluffy. As the plant dries it forms a brittle surface layer whicis easily separates from the wood.

While the fungus is distributed over a large part of the United States, it occurs in greatest abundance in the southern half east of the Rockies. In the north it is introduced principally on infected pine. Ties are usually abundantly infected before reaching destination. Fortunately the fungus does not produce any appreciable rot in the sapwood which it attacks, although the mycelium penetrates to a considerable extent. Hence the inspector need not discriminate against it. Hypocrea Citrina

(Plate II, Fig. 4; Plate VI. Figs. 3 and 4)

This is one of the fungi which grow flat on the surface of the wood. It closely resembles a spot of yellow paint and forms a crust about $\frac{1}{16}$ inch thick. The spores are borne in cavities just beneath the surface of the fruit-body. It was noted several times, particularly on beech. The wood beneath the fruit-bodies is markedly bleached, but the tissues are not seriously disintegrated. In its action on the wood it behaves a good deal like Schizophyllum commune and should thus be classed with the slow-acting wood destroyers.

Hypoxylon COHAERENS

(Plate II, Fig. 1; Plate V, Figs. 5 and 7 )

The fruiting-bodies of this fungus consist of more or less globose buttons, usually not exceeding $\frac{1}{16}$ inch in diameter. In the young stages these are no larger than a pin head and are often covered with a claycolored "bloom." When mature they are black.

This fungus has a rather wide distribution in the United States, but has never been reported as serious outside the central hardwood region, where it is limited to beech. The sapwood is first attacked, but finally the heartwood is invaded. The configuration of the rot is peculiar, as the fungus attacks the wood in small, irregular "islands," usually radially elongate, which are bleached out and bounded by narrow brown lines representing the sound wood. This gives an intricate tracery of brown lines on a lighter background. In more advanced stages of the rot the brown lines may disappear, giving a more or less uniform bleached appearance to the wood. The rot is a serious one and should be culled, as the infected areas show a marked softening and disintegration of the fiber. 


\section{Hypoxylon Coccineum}

\section{(Plate II, Fig. 2; Plate V, Figs. 6 and 8)}

The fruiting-bodies of this species are of the same type as the preceding, but differ in being considerably larger, although not usually exceeding $I / 4$ inch in diameter. They are reddish-brown in color but may become somewhat blackened in age. The distribution is essentially the same as for the preceding species, and the rot is quite similar. The fungus is also limited to beech.

\section{Daldinla Concentrica}

\section{(Plate III, Fig. 2; Plate VI, Figs. 1 and 2)}

This fungus appears as large more or less globular "buttons" up to 1 or 2 inches in diameter. These are of the color and consistency of charcoal within and blackish, tinged with olive green on the outside surface, which is quite smooth. The spores are borne in a layer of small cavities just beneath the crust and ooze out through minute openings. A scant mycelium forms over the surface of the wood, which, together with the dark brown spores which have collected around the fruit-bodies, blacken it. The fungus was found on soft maple and white elm ties, but is also known to attack various hardwoods in different parts of the country. The rot is severe and ties bearing the fungus should be culled.

\section{Exidia Glanduloja}

\section{(Plate III, Fig. 4; Plate V, Figs. 9-11)}

This fungus is black and jelly-like. It grows spread out flat on the surface of the wood. When developing on the ends of ties it often follows the sapwood around in a ring, but it may also overgrow the heartwood. When moist it is slimy to the touch with a much crumpled outer surface, but when dry it shrinks to a very thin, shiny black brittle membrane which shows no crumpling. The spores are white and are borne on the exposed surface of the fruit-bodies.

This was one of the fungi commonly encountered on hardwoods, mainly red gum and beech, in the region investigated. It is widely distributed over the United States, but heretofore has not been reported as causing serious decay in structural timbers. It should be discriminated against, at least in the South, where it can apparently decay the less durable woods in a comparatively short time.

\section{Blue Stain (Ċeratostomella Spr.)}

(Plate VII, Figs. 8, 10 and 11 )

This fungus frequently appears on the ends or surface of freshly cut timbers of both conifers and hardwoods. In many cases the mycelium is scanty, but in others it may form a luxuriant, matted growth, at first whitish but soon becoming brownish-black. The fruiting-bodies are seated either in this matted mycelium or directly on the 
surface of the wood. They consist of minute, flask-shaped structures, often with long, bristle-like necks which are visible to the unaided eye as rigid, black, brittle hairs on the surface of the wood.

The most characteristic feature of these fungi, however, is the grayish-blue discoloration produced. The stain may be quite uniform over considerable areas, or it may be limited. It is caused by the penetration of the mycelium into the sapwood mainly through the pith rays. As the fungus lives mainly on the starches, sugars, etc., stored in the pith rays, it does not affect the strength of the wood and hence is of no economic importance in connection with tie timbers.

In the region investigated both pine and red gum are particularly susceptible.

Olive-Black Mold (Lasiosphaerta Pezizula) (Plate III, Fig. 1; Plate VII, Fig. 9)

This fungus was frequently seen on the ends of red gum and beech ties. It develops as a blackish mold-like. growth which is distinctly tinged with olive green. The mycelium is compact, and upon it are seated minute, depressed, spherical, brownish-black fruiting-bodies much smaller than a pin head.

The mycelium penetrates the wood to a considerable extent. It produces a bluish-black discoloration quite similar to the blue stain, but does not appreciably attack the fiber, and hence need not be discriminated against. 


\section{PLATE I}

Fig. 1. Stereum rameale growing on the end of a red gum tie.

Fig. 2. Polystictus versicolor on the side of a red gum tie.

Fig. 3. Peniophora gigantea on the side of a yellow pine tie.

Fig. 4. Lenzites sepiaria on the end of a yellow pine tie lying on the ground. 

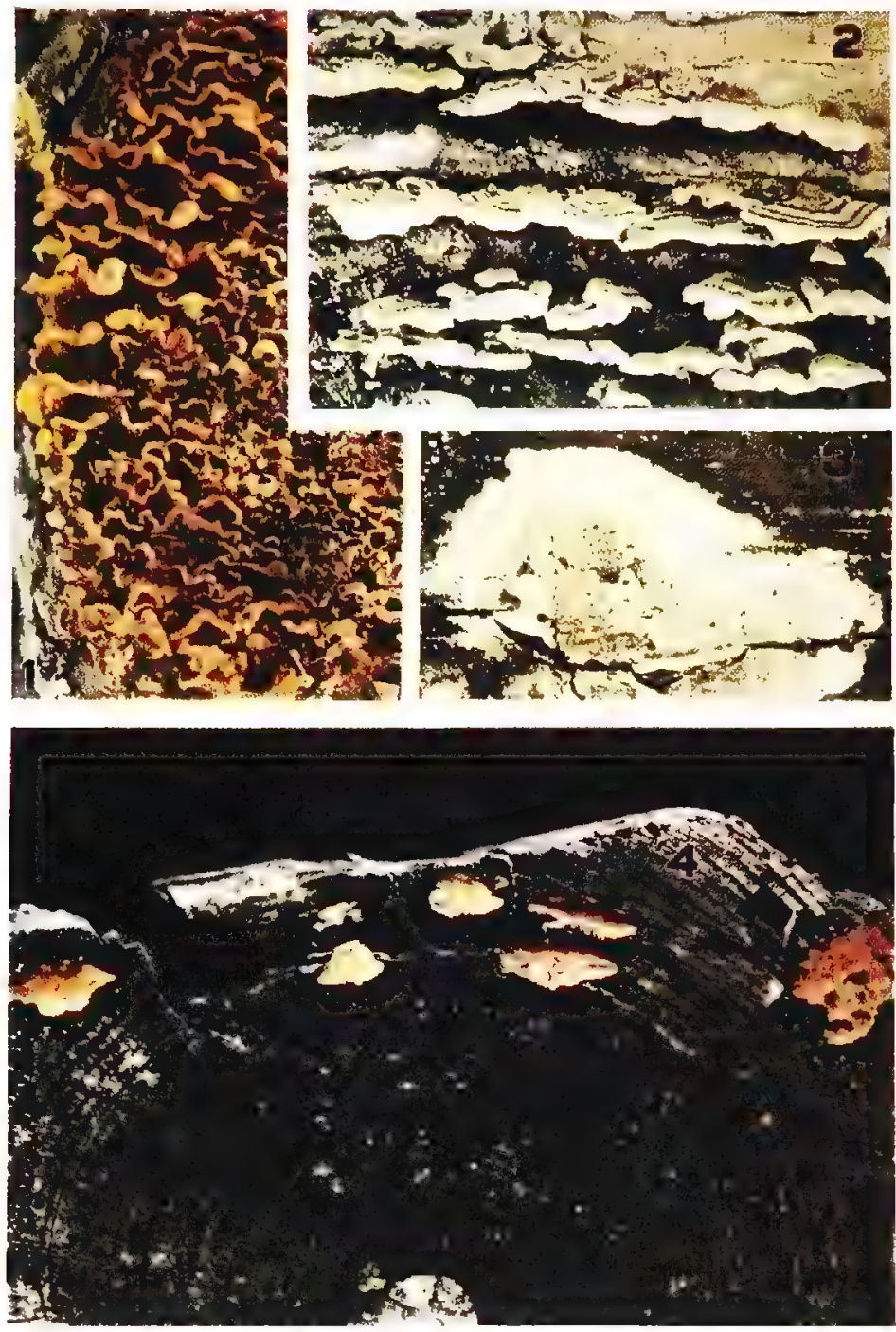


\section{PLATE II}

Fig. 1. Hypoxylon cohaerens on the end of a beech tie.

Fig. 2. Hypoxylon coccineum on the end of a beech tie.

Fig. 3. Lenzites betulina on the end of a red gum tie.

Fig. 4. Hypocrea citrina on the end of a beech tie. The white area is paint. 

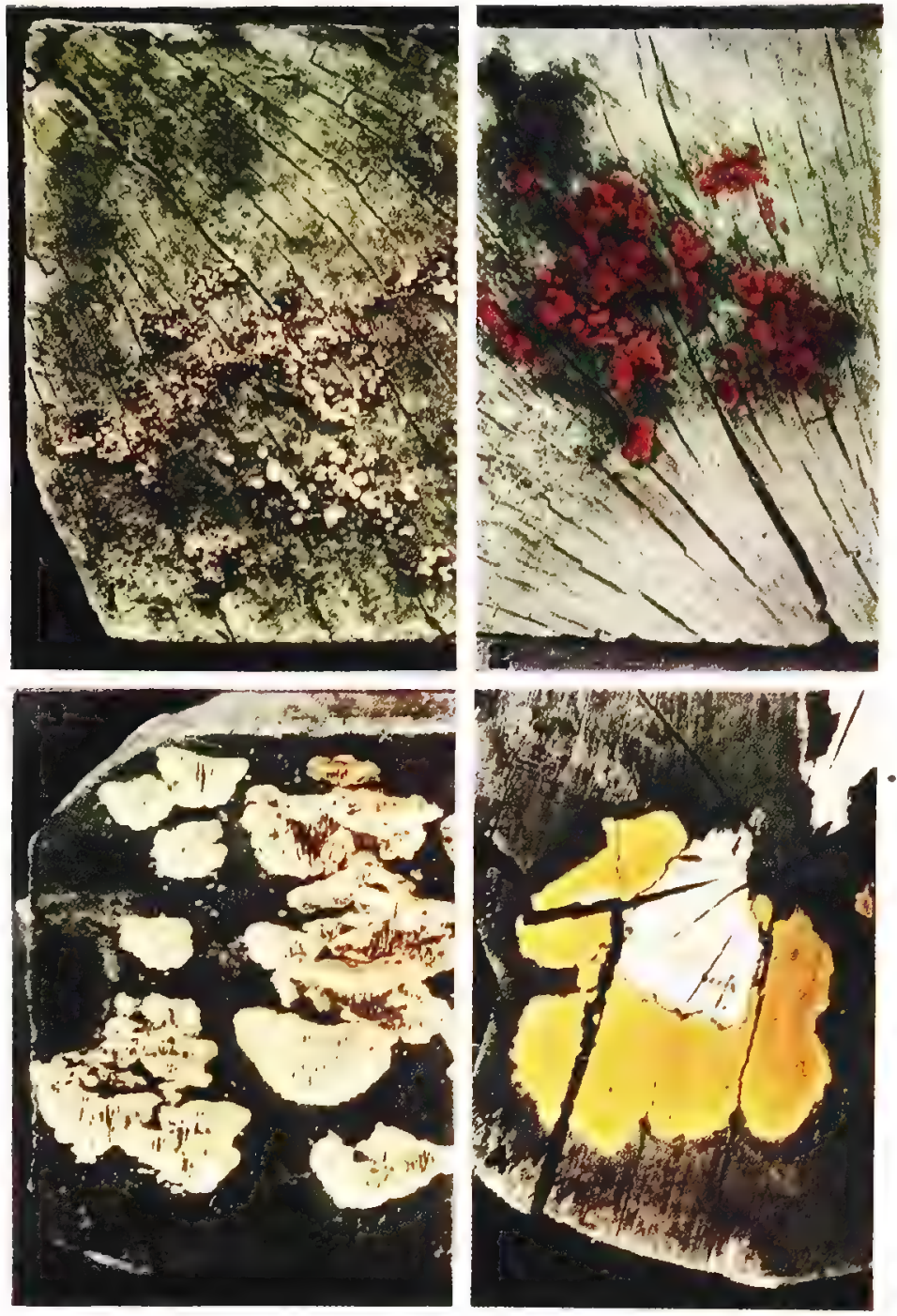


\section{PLATE III}

Fig. 1. An olive-black mold, Lasiosphaeria pezizula, on the end of a red gum tie.

Fig. 2. Daldinia concentrica on the end of a white elm tie. The surface of the wood is blackened from spores and inycelium.

Fig. 3. Stereum fasciatum on sapwood at the end of a white oak tie.

Fig. 4. Exidia glandulosa on sapwood at the end of a beech tie. 

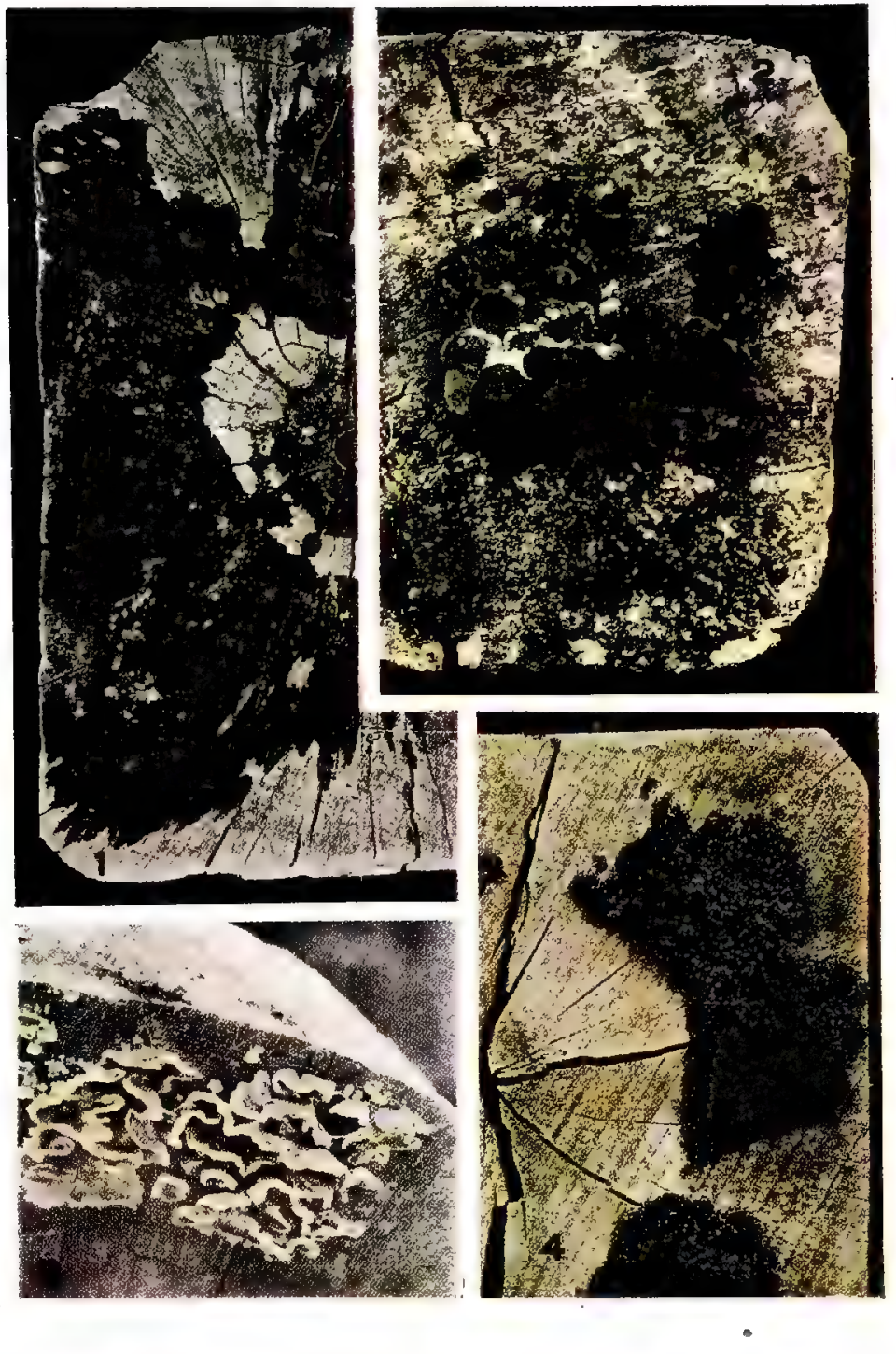


\section{PLATE IV}

Fig. 1. Peniophora gigantea on the end of a comparatively new sound yellow pine tic. The radiating white streaks are mycelium intermixed with exuding resin.

Fig. 2. Longitudinal section of pine wood beneath the sporophore of Peniophora gigantea shown in Plate I, Fig. 3. Note that the wood is not decayed.

Fig. 3. Cross section of the same tie.

Fig. 4. Cross section of white oak tic, shown in Plate III, Fig. 3, sap-rotted by Stereum fasciatum.

Fig. 5. Cross section of red oak tie rotted by Lenzites betulina.

Fig. 6. Longitudinal section of same tie. The light areas are thoroughly rotted.

Fig. 7. Longitudinal section of red gum tie shown in Plate I, Fig. 2, rotted by Polystictus versicolor.

Fig. 8. Cross section of same tie showing complete de- cay throughout.

Fig. 9. Cross section of a white oak tie showing the sap-rot produced by Polystictus versicolor and Stereum fasciatum invading the heartwood. 

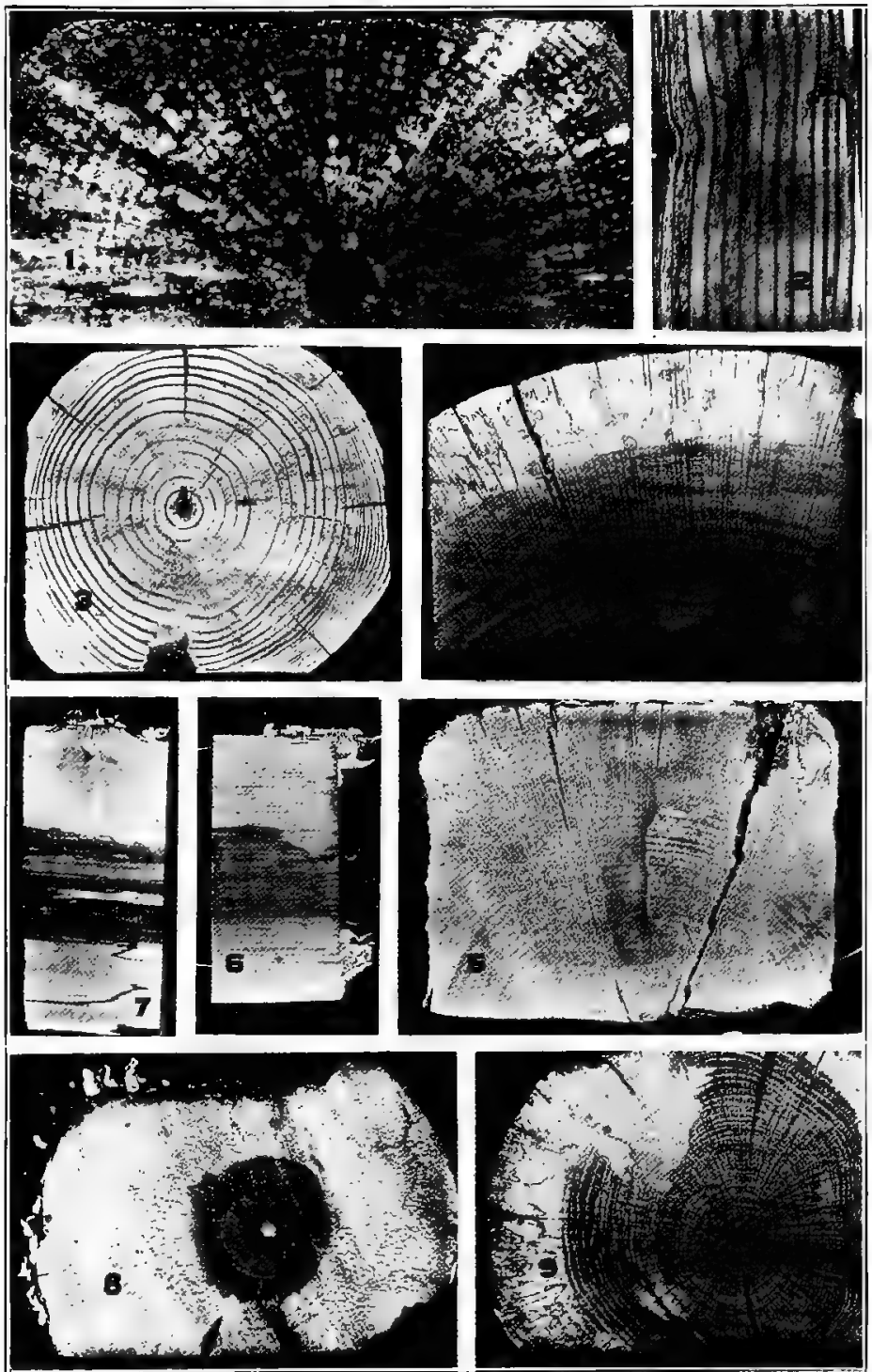


\section{PLATE V}

Fig. 1. Longitudinal section of yellow pine tie shown in Plate I, Fig. 4, rotted by Lenzites sepiaria. Note that the rot occurs in the form of large dark brown pockets.

Fig. 2. Cross section of the same tie. The dark streaks show wood in the early stages of decay.

Fig. 3. Cross section of red gum tie shown in Plate I, Fig: 1, rotted by Stereum rameale.

Fig. 4. Longitudinal section of same tie. The lighter areas" are severely decayed.

Fig. 5. Longitudinal section of beech tie shown in Plate II, Fig. 1, rotted by Hypoxylon cohaerens.

Fig. 6. Longitudinal section of beech tie shown in Plate II, Fig. 2, rotted by Hypoxylon coccineum.

Fig. 7. Cross section of beech tie shown in Plate II, Fig. 1, rotted by Hypoxylon cohaerens.

Fig. 8. Cross section of beech tie shown in Plate II, Fig. 2, rotted by Hypoxylon coccineum.

Fig. 9. Cross section of beech tie shown in Plate III, Fig. 4, rotted by Exidia glandulosa.

Fig. 10. Longitudinal section of same tie.

Fig. 11. Cross section of beech tie sap-rotted by Exidia glandulosa. 


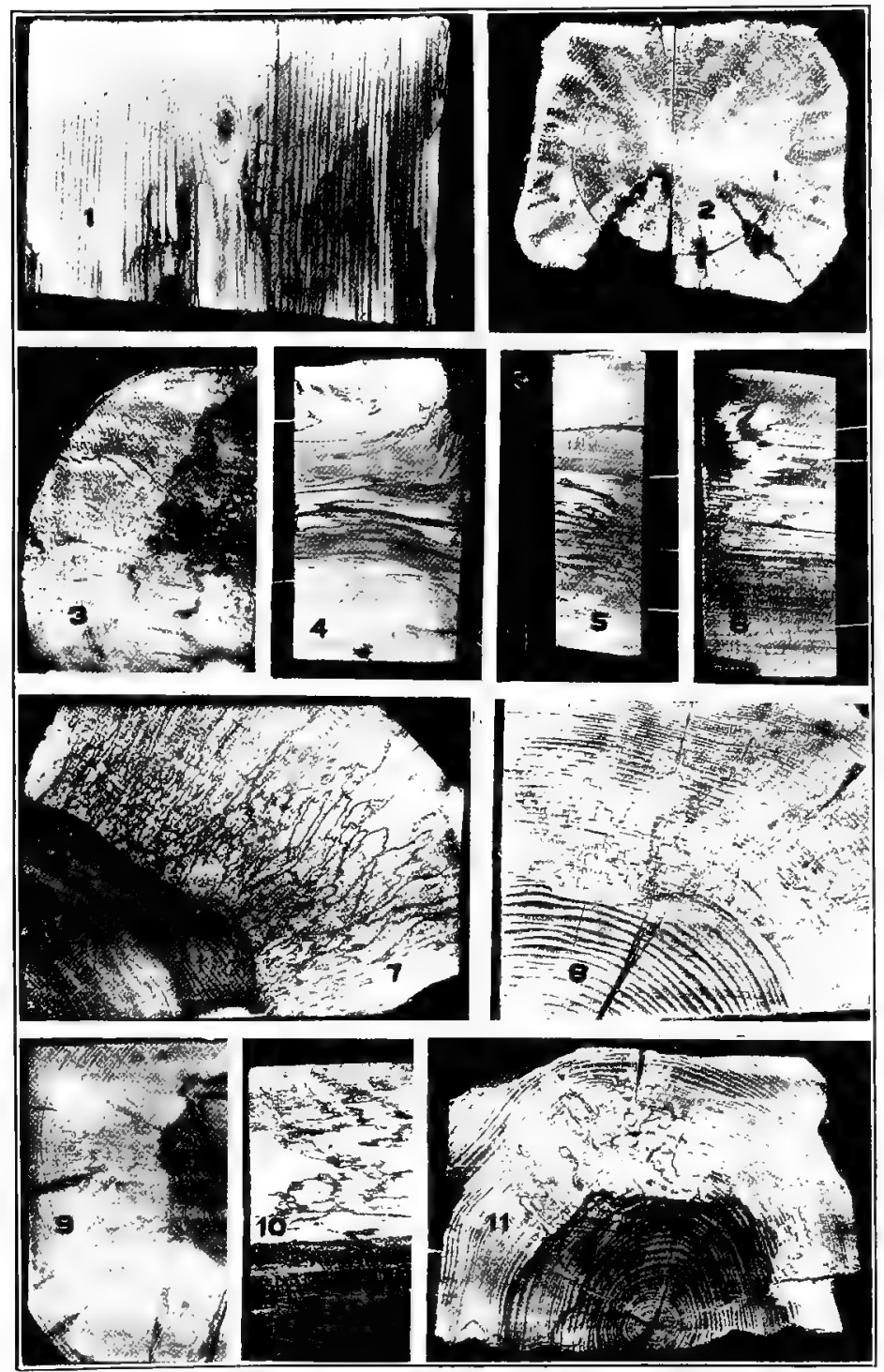




\section{PLATE VI}

Fig. 1. Cross section of severely rotted white elm tie shown in Plate III, Fig. 2, rotted by Daldinia concentrica.

Fig. 2. Longitudinal section of the same tie.

Fig. 3. Longitudinal section of beech tie shown in Plate II, Fig. 4, rotted by Hypocrea citrina.

Fig. 4. Cross section of same tic. The whitened area shows the extent of the rot.

Fig. 5. Schizophyllum commune fruiting on the end of a persimmon tie.

Fig. 6. Cross section of the same tie. The whitened areas are considerably decayed.

Fig. 7. Longitudinal section of the same tie.

Fig. 8. Schizophyllum commune on the end of a comparatively new yellow pine tie.

Fig. 9. Longitudinal section of the same tie. Note that there is no noticeable decay.

Fig. 10. Cross section of the same tie. 


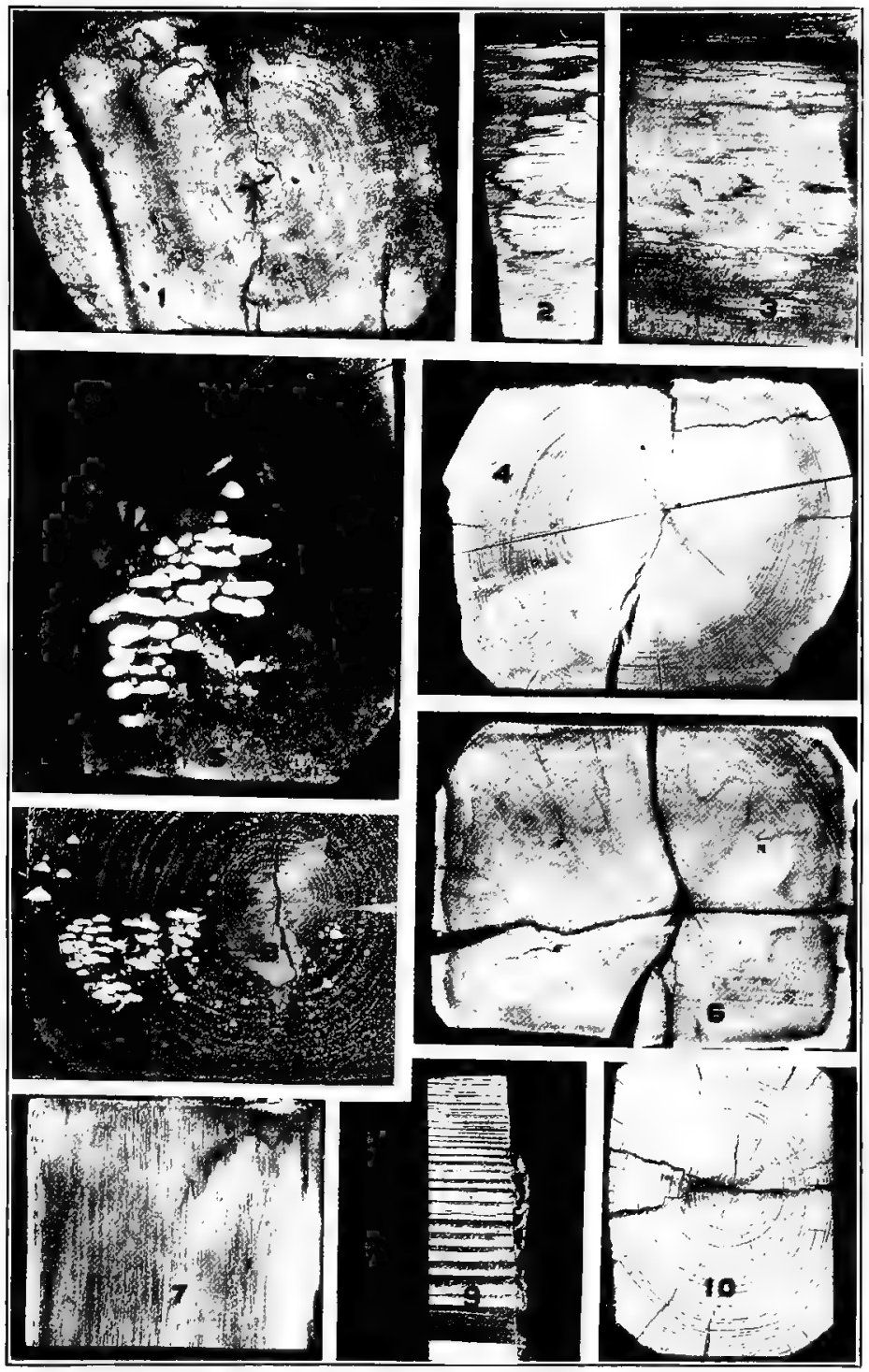




\section{PLATE VII}

Fig. 1. Trametes sepium fruiting on sapwood at the end of a white oak tie.

Fig. 2. Pholiota adiposa growing from the rotten heartwood through a large crack on the side of a beech tie. This tie was heart-rotted when cut.

Fig. 3. Hydnum erinaceum fruiting on the heartwood at the end of a beech tie. Tie heart-rotted when cut.

Fig. 4. Panus stipticus fruiting on the sicle of a red oak tie and producing a sap-rot.

Fig. 5. Gloeoporus conchoides fruiting mainly on the heart of a red oak tie.

Fig. 6. Cross section of heart rot in beech tie shown in Fig. 2, produced by Pholiota adiposa.

Fig. 7. Daedalea confragosa fruiting on the end of a willow tie.

Fig. 8. Longitudinal section of blue-stained red gum tie shown in Fig. 10.

Fig. 9. Longitudinal section of red gum tie shown in Plate III, Fig. 1. Infected at the end with the olive-black mold, Lasiosphaeria pezizula (B. \& C.) Sacc.

Fig. 10. The blue-stain fungus (Ceratostomella sp.) on the end of a red gum tie. The white areas are in part the mycelium of a mold intermixed with the blue-stain.

Fig. 11. Cross section of the same tie, about an inch and a half from the end. 


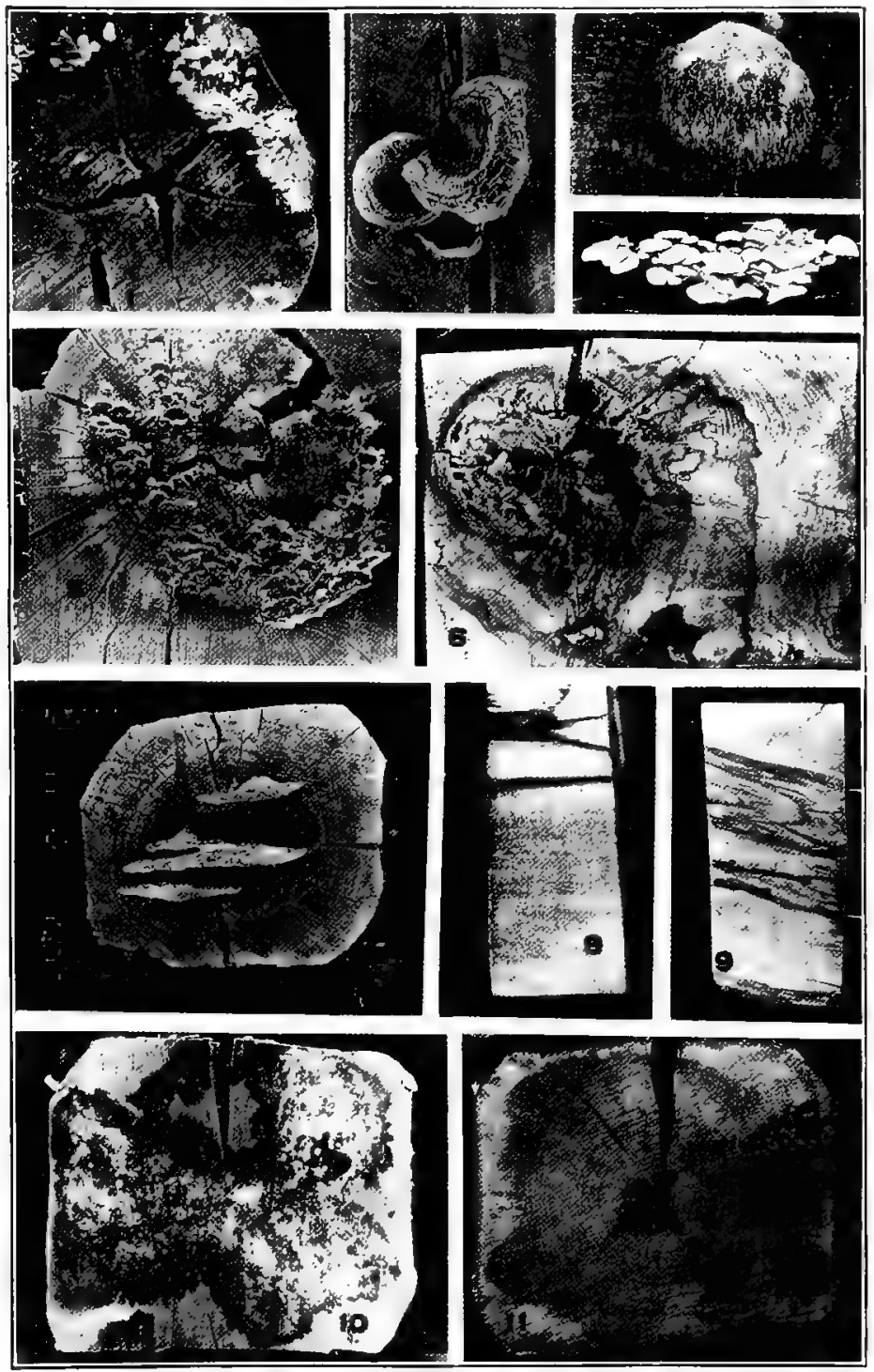




\section{PLATE VIII}

Fig. 1. Polystictus abietinus on the side of a pine tie in track.

Fig. 2. Lentinus lepideus on the side of a rotten hemlock tie removed from track.

Fig. 3. Polystictus pargamenus on a paper birch sapling in the rvoods.

Fig. 4. Fomes roseus on the end of a hemlock tie in track.

Fig. 5. Lenzites trabea on the end of a hardwood tie in track. 


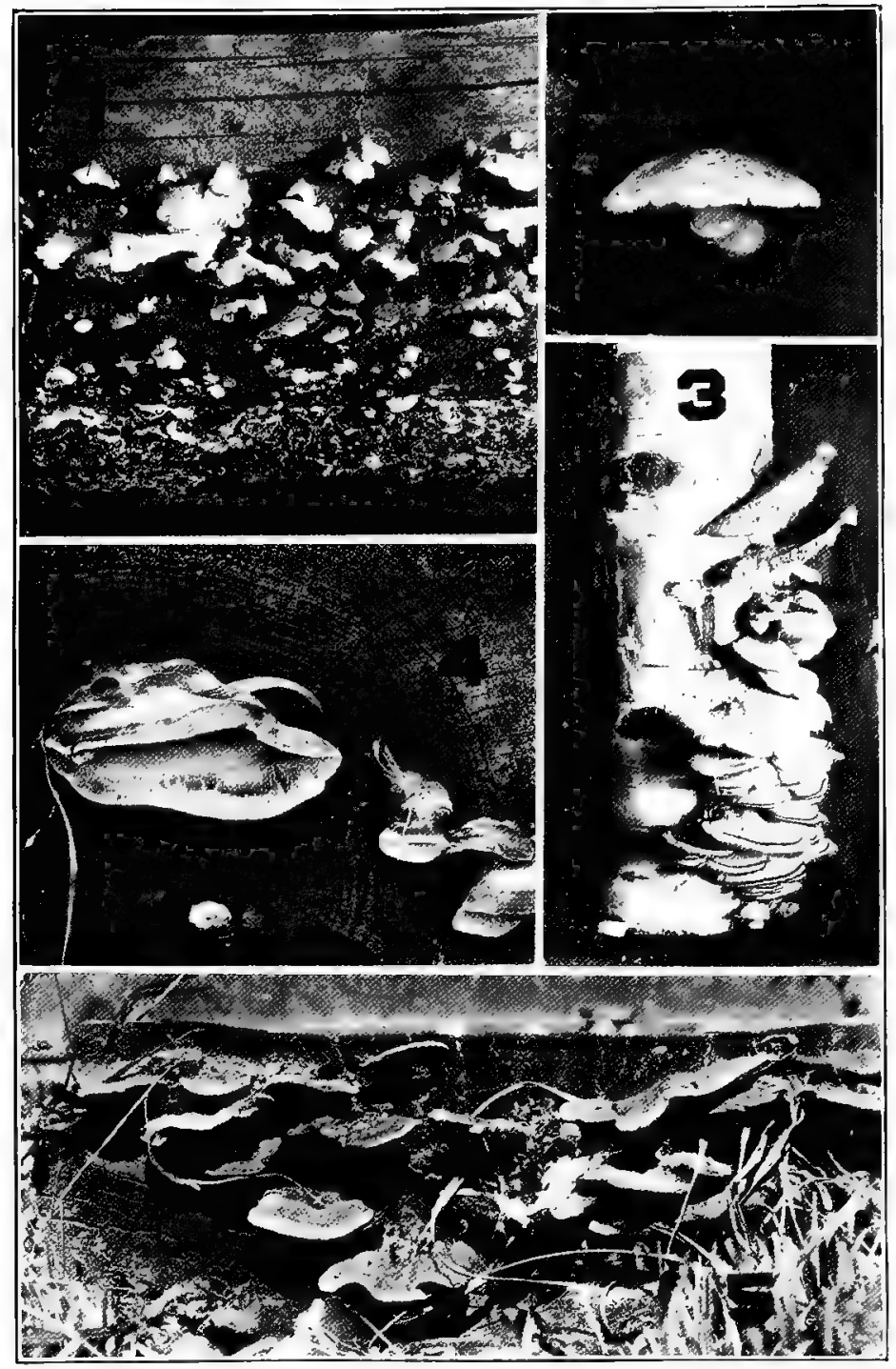






